\title{
OCCURRENCE OF MUSCARINIC ACETYLCHOLINE RECEPTORS IN WILD TYPE AND CHOLINERGIC MUTANTS OF CAENORHABDITIS ELEGANS
}

\author{
J. G. CULOTTI ${ }^{2}$ AND W. L. KLEIN \\ Departments of Neurobiology and Physiology and Biochemistry, Molecular and Cell Biology, Northwestern University, \\ Evanston, Illinois 60201
}

Received December 14, 1981; Revised August 11, 1982; Accepted September 3, 1982.

\begin{abstract}
Crude homogenates of the nematode worm Caenorhabditis elegans were shown to bind the cholinergic antagonists $\left[{ }^{3} \mathrm{H}\right] N$-methylscopolamine and quinuclidinyl benzilate $\left(\left[{ }^{3} \mathrm{H}\right] \mathrm{QNB}\right)$ with high affinity. The dissociation constant for $\left[{ }^{3} \mathrm{H}\right] N$-methylscopolamine binding determined from equilibrium saluration experiments $\left(K_{\mathrm{D}}=3.7 \times 10^{-10} \mathrm{M}\right)$ was in good agreement with that determined from forward and reverse rate constants $\left(K_{\mathrm{D}}=k_{\text {off }} / k_{\text {on }}=5 \times 10^{-10} \mathrm{M}\right)$. These binding sites were blocked stereospecifically by the $(+)$ enantiomer of the muscarinic antagonist benzetimide, as would be expected of true muscarinic receptors. Furthermore, competition experiments with unlabeled cholinergic agonists and antagonists indicate that $\left[{ }^{3} \mathrm{H}\right] \mathrm{QNB}$ and $\left[{ }^{3} \mathrm{H}\right] N$-methylscopolamine bind to the same sites in nematode homogenates and that these sites are similar but not identical to muscarinic receptors in vertebrates. The concentration of $\left[{ }^{3} \mathrm{H}\right] N$-methylscopolamine and $\left[{ }^{3} \mathrm{H}\right] \mathrm{QNB}$ binding sites in adult populations of wild-type nematodes was approximately $10 \mathrm{fmol} / \mathrm{mg}$ of protein. This was approximately 4 -fold lower than the concentration of binding sites in young (L1 and L2 stage) juveniles. These stage-specific differences in binding site concentrations parallel differences in acetylcholinesterase activity in larval and adult nematodes (Culotti, J., G. von Ehrenstein, M. R. Culotti, and R. L. Russell (1981) Genetics 97: 281-305). Three methods of elevating cholinergic agonist levels in vivo were attempted in order to determine whether regulation of muscarinic receptors occurs in nematodes as it does in vertebrates (Klein, W. L., N. Nathanson, and M. Nirenberg (1979) Biochem. Biophys. Res. Commun. 90: 506-512). Two methods involved prolonged in vivo inhibition of acetylcholinesterase activity, while the third method involved in vivo treatment with the potent agonist levamisole. All three methods failed to reveal down regulation of muscarinic receptors, suggesting that this regulatory mechanism may not exist in nematodes. Finally, phenotypic revertants of acetylcholinesterase-deficient double mutants as well as a class of agonist-resistant mutants (Lewis, J. A., C. H. Wu, H. Berg, and J. H. Levine (1980a) Genetics 95: 905-928) were screened for possible alterations in $\left[{ }^{3} \mathrm{H}\right] \mathrm{QNB}$ or $\left[{ }^{3} \mathrm{H}\right] N$-methylscopolamine binding levels. None of these mutants exhibited gross deficiencies in $\left[{ }^{3} \mathrm{H}\right] \mathrm{QNB}$ or $\left[{ }^{3} \mathrm{H}\right] N$-methylscopolamine binding, although partial deficiencies might have gone undetected by the methods used here. Our binding studies show that muscarinic receptors, which mediate a large proportion of cholinergic signaling in advanced vertebrates, are also present in the very simple nematode system.
\end{abstract}

A promising organism for the study of neurotransmitter-related behavioral and developmental phenomena is

\footnotetext{
1 This research was supported by National Institutes of Health Grant NS16510 to J. C., a Muscular Dystrophy Association grant to J. C., and National Institutes of Health Grant NS15299 to W. K. Sperial thanks to Mary Carton and Teresa Perney for their excellent technical assistance and to William James and Chris DeCrease for their preliminary experimental results on nematode receptors. We are grateful to Drs. Ariens and Van Bever of Janssen Pharmaceutica for their generous gift of the stereoisomers of benzetimide.

${ }^{2}$ To whom correspondence should be addressed at Department of
}

the free-living nematode worm Caenorhabditis elegans. This organism is genetically and biochemically tractable and exhibits an anatomical simplicity that has allowed an extensive characterization of its embryonic and postembryonic development (Deppe et al., 1978; von Ehrenstein and Schierenberg, 1980; Sulston and Horvitz, 1977; E. Schierenberg and J. Sulston, personal communication). These studies have provided a nearly complete picture of the cell lineages that give rise to the relatively

Neurobiology and Physiology, 4-140 Hogan Hall, Northwestern University, Evanston, IL 60201. 
simple nervous system of this organism, and a wiring diagram for the entire nervous system of the wild type is available (White et al., 1976; Albertson and Thomson, 1978; Ware et al., 1975; Ward, et al., 1975; Hall, 1978; J. White, personal communication). A number of behavioral mutants with defects in specific lineages or in the wiring diagram have been isolated and characterized (Horvitz and Sulston, 1980; Sulston and Horvitz, 1981; Chalfie et al., 1981). However, in relatively few cases has the molecular defect in these or any other neurological mutants been determined.

Another approach to genetic studies of the nervous system in the nematode has been to isolate mutants with defects in known or suspected neurotransmitter-related funclions in order to study the effects of such known specific molecular defects on the extremely well-characterized nervous system of this organism. These studies have been initiated by the isolation and behavioral, molecular, and histochemical characterization of acetylcholinesterase deficient mutants of $C$. elegans (Johnson et al., 1981; Culotti et al., 1981). The behavior of acetylcholinesterase mutants and of the wild type treated with an acetylcholinesterase inhibitor provide circumstantial evidence that acetylcholine is a neurotransmitter in nematodes, as has been established by electrophysiological techniques for the anatomically similar parasitic nematode Ascaris lumbricoides (del Castillo et al., 1963).

We have undertaken here a search for possible acetylcholine receptors in the nematode with the aim of eventually extending our genetic studies to these important components of cholinergic synapses. In vertebrates, acetylcholine receptors are distinguished pharmacologically (Koelle, 1975) and physiologically (Purves, 1976) as being either nicotinic or muscarinic. The work presented here is based on the introduction of the high affinity muscarinic ligands $\left[{ }^{3} \mathrm{H}\right] \mathrm{QNB}$ (Yamamura and Snyder, 1974a) and $\left[{ }^{3} \mathrm{H}\right] N$-methylscopolamine (Burgermeister et al., 1978) as sensitive probes for measuring and characterizing muscarinic receptors in a variety of vertebrate systems. Muscarinic receptors have been found in great abundance in the vertebrate CNS (Yamamura et al., 1974) and in peripheral targets (Galper et al., 1977; Yamamura and Snyder, 1974b). They exist in multiple binding states (Klein, 1980a) likely related to a functional inhibition of adenylate cyclase (Nathanson et al., 1977), and their concentration is regulated by cholinergic stimulation in vitro (Klein et al., 1979) and in vivo (reviewed Klein, 1980b). They also have been found in advanced invertebrates such as Drosophilia (Dudai and BenBarak, 1977; Haim et al., 1979). Results presented here, which extend our preliminary report (James et al., 1980), indicate that nematode extracts possess acetylcholine receptors which bind the muscarinic antagonists $\left[{ }^{3} \mathrm{H}\right]$ QNB and $\left[{ }^{3} \mathrm{H}\right] N$-methylscopolamine with high affinity. The putative muscarinic receptors are present in larvae and adults in concentrations consistent with their presumed cholinergic function in vivo. These receptors do not appear to be down regulated by treatments designed to elevate in vivo cholinergic agonist levels for prolonged periods of time. Preliminary results on $\left[{ }^{3} \mathrm{H}\right] \mathrm{QNB}$ binding levels in two classes of mutants selected for possible acetycholine receptor defects are presented. To our knowledge, this report is the first to describe receptorbinding sites for any transmitter in the nematode system.

\section{Materials and Methods}

Nematode strains. Wild-type Caenorhabditis elegans var. Bristol was originally obtained from Brenner (1974). Acetylcholinesterase-deficient mutations of C. elegans were ace-1 (p1000)X (Johnson et al., 1981), ace-2 (g73)I, or ace-2 (g72)I (Culotti et al., 1981). Strains carrying the levamisole-resistant mutations unc-29 (e1072)I, unc-63 (e384)I, unc-38 (e904)I, unc-74 (x19)I, unc-50 (e306)III, lev-1 (x21)IV, lev-7 (x13)I, lev-8 (x15) X, lev-9 (x16)I, unc$22(\mathrm{e} 66) \mathrm{IV}$, lev-10 (x17)I, lev-11 (x12)I, and unc-68 (e540) V were kindly provided by Jim Lewis (Columbia University) or by the Caenorhabditis Genetics Center in Columbia, MO (Peg Swanson, curator).

Aldicarb-resistant mutants were isolated following mutagenesis with ethylmethane sulfonate (Brenner, 1974) of the acetylcholinesterase double mutant strain GG198 (p1000, g73). $\mathrm{F}_{1}$ adults were allowed to lay eggs on standard growth plates (Brenner, 1974) containing $100 \mu \mathrm{M}$ Aldicarb. Most eggs hatched, but most of the $\mathrm{F}_{2}$ individuals were severely inhibited for growth and locomotion. $\mathrm{F}_{2}$ individuals that hatched and grew better and/or moved better than the norm were picked and cloned. Mutants with the most interesting phenotypes (these were of two classes: paralyzed mutants or those that moved better than the acetylcholinesterase double mutant) were used for the experiments described here. These included independently derived strains NW7, NW17, NW27, NW50, NW57, NW86, NW96, NW100, and NW119. Strain CB450 which carries an unc-13 mutation was included since it was also discovered to be Aldicarb resistant. A genetic and morphologic description of these mutants will be the subject of another communication (J. G. Culotti, manuscript in preparation).

Large batches of nematodes were grown on large cake pans containing standard growth agar seeded with 5 to $10 \mathrm{gm}$ of Escherichia coli. Such a plate typically yielded 2 to $5 \mathrm{gm}$ wet weight of healthy nematodes. Essentially $100 \%$ pure populations of L1 and L2 stage juveniles were obtained in some cases by dissolving large populations of adult nematodes with $4 \%$ hypochlorite to release fertilized eggs developing in utero. Eggs were collected by centrifugation then incubated on NGM growth plates with $E$. coli for 10 to $12 \mathrm{hr}$ at $20^{\circ} \mathrm{C}$ to allow hatching. The larvae were harvested and cleaned by standard procedures or allowed to grow at $20^{\circ} \mathrm{C}$ for 70 to $90 \mathrm{hr}$ before harvesting as synchronous adult populations. In other instances, larvae or adults were enriched from asynchronous populations by differential settling in water and selection of slow-settling or fast-settling individuals, respectively.

For binding assays, large scale cultures were grown on NGM plates containing added $E$. coli OP50, harvested, cleaned according to the method of Sulston and Brenner (1974), and stored frozen at $-70^{\circ} \mathrm{C}$. Crude homogenates were prepared by freeze-powdering in liquid nitrogen. Binding was monitored in freeze-powdered homogenates by incubating an aliquot containing 0.5 to $1.0 \mathrm{mg}$ of protein in a 1-ml solution of $50 \mathrm{~mm}$ sodium phosphate (pH 7.4), and $1 \times 10^{-10}$ to $2 \times 10^{-9} \mathrm{M}\left[{ }^{3} \mathrm{H}\right] \mathrm{QNB}$ or $\left[{ }^{3} \mathrm{H}\right] N$ - 
methylscopolamine (New England Nuclear). An incubation time of $90 \mathrm{~min}$ was used except where noted. Incubations were filtered on Whatman GF/C filters and washed two times with $5 \mathrm{ml}$ and finally with $40 \mathrm{ml}$ of cold phosphate buffer within a time span of 30 sec. Filters were then dried and counted in an appropriate scintillation cocktail. Nonspecific binding was determined by measuring radioligand binding in the presence of $10^{-6} \mathrm{M}$ or $10^{-5} \mathrm{M}$ atropine in the incubation mixture. Protein was assayed by the dye-binding method of Bradford (1976) using bovine $\gamma$-globulin as the standard. Protein determinations were linear with amount of added crude homogenate and internal controls were perfectly additive. All mutant receptor assays were carried out at saturating levels of $\left[{ }^{3} \mathrm{H}\right] N$-methylscopolamine or $\left[{ }^{3} \mathrm{H}\right] \mathrm{QNB}$ (1 to 2 $\left.\times 10^{-9} \mathrm{M}\right)$.

\section{Results}

The kinetics of total and nonspecific $\left[{ }^{3} \mathrm{H}\right] N$-methylscopolamine binding to nematode homogenates are shown in Figure 1. Nonspecific binding (measured in the presence of $10^{-5} \mathrm{M}$ atropine) reached maximal level very rapidly and remained constant for at least $120 \mathrm{~min}$, whereas total binding and specific binding (total minus nonspecific) increased continuously with time for $20 \mathrm{~min}$ then plateaued. Assuming that this binding represents a bimolecular reaction between ligand and binding sites, the forward rate constant for the binding reaction is calculated to be approximately $3.0 \times 10^{6}$ liter $/ \mathrm{mol}-\mathrm{sec}$. Similarly, the kinetics of $\left[{ }^{3} \mathrm{H}\right] \mathrm{QNB}$ binding (not shown) leads to a calculated forward rate constant of $4.5 \times 10^{6}$ liter/mol-sec.

In another experiment, binding was allowed to proceed for $60 \mathrm{~min}$, at which time $10^{-5} \mathrm{M}$ atropine was added to

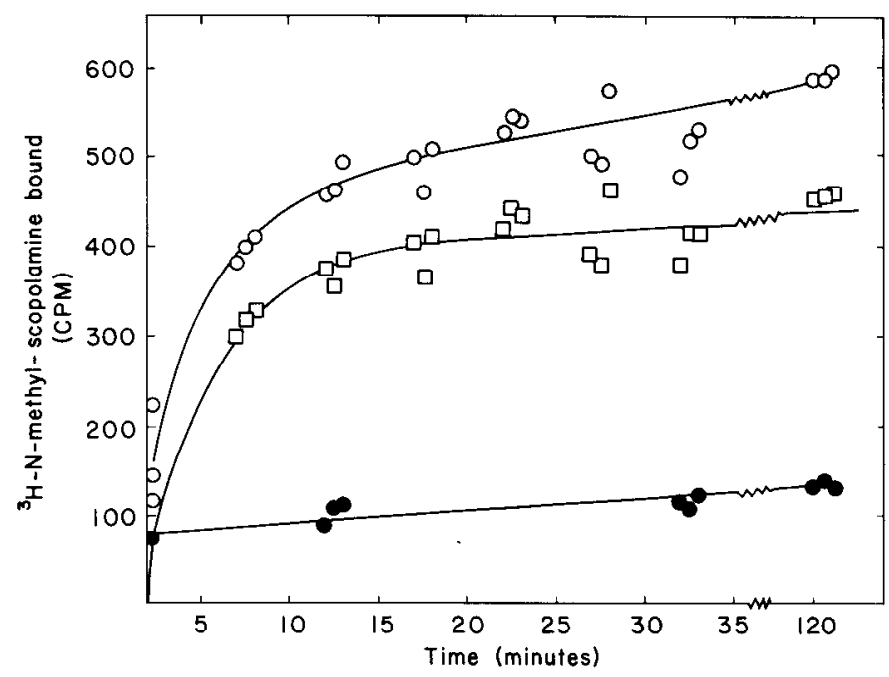

Figure 1. Rate of $\left[{ }^{3} \mathrm{H}\right] N$-methylscopolamine binding to crude homogenates of $C$. elegans. A crude homogenate of wild-type C. elegans was incubated at $23^{\circ} \mathrm{C}$ with $1 \mathrm{~nm}\left[{ }^{3} \mathrm{H}\right] N$-methylscopolamine for total binding $(O)$ or $1 \mathrm{nM}\left[{ }^{3} \mathrm{H}\right] N$-methylscopolamine plus $10^{-5} \mathrm{M}$ atropine for nonspecific binding (O) in $50 \mathrm{~mm}$ sodium phosphate buffer ( $\mathrm{pH} 7.4)$. At the indicated times, $1-\mathrm{ml}$ samples containing $0.7 \mathrm{mg}$ of crude protein were filtered and assayed as described in "Materials and Methods." Specific binding $(\square)$ is plotted as the difference between total binding and nonspecific binding.

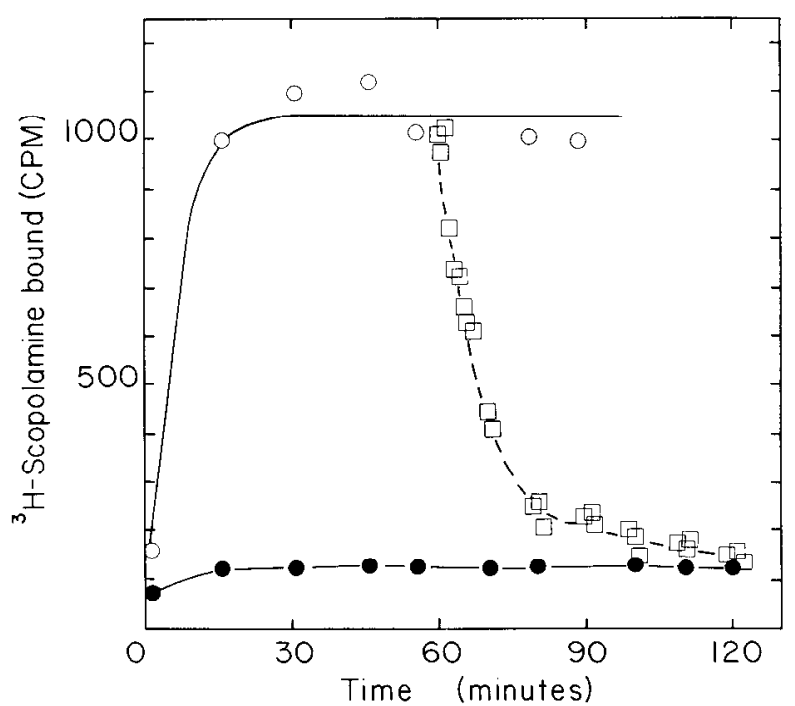

Figure 2. Rate of $\left[{ }^{3} \mathrm{H}\right] N$-methylscopolamine dissociation. A crude homogenate of wild-type $C$. elegans was incubated at $23^{\circ} \mathrm{C}$ with $1 \mathrm{nM}\left[{ }^{3} \mathrm{H}\right] N$-methylscopolamine for total binding (O) or with $1 \mathrm{nM}\left[{ }^{3} \mathrm{H}\right] \mathrm{N}$-methylscopolamine plus $10^{-5} \mathrm{M}$ atropine for nonspecific binding (O). At the indicated times, $1-\mathrm{ml}$ samples containing $0.63 \mathrm{mg}$ of crude protein were filtered and assayed as described in "Materials and Methods." At $60 \mathrm{~min}$ after mixing crude homogenates with $\left[{ }^{3} \mathrm{H}\right] N$-methylscopolamine, $10^{-5} \mathrm{M}$ atropine was added to portions of some reaction mixtures and the $\left[{ }^{3} \mathrm{H}\right] N$-methylscopolamine remaining bound $(\square)$ was measured at the indicated times thereafter. Points represent the average of three separate assays. Standard errors were all less than $5 \%$ of the average for each point.

the incubation mixture to prevent further binding. Levels of bound $\left[{ }^{3} \mathrm{H}\right] \mathrm{N}$-methylscopolamine were determined at various intervals thereafter with results shown in Figure 2. The rate constant for dissociation calculated from this experiment was approximately $1.6 \times 10^{-3} / \mathrm{sec}$. The apparent dissociation constant $\left(K_{\mathrm{D}}\right)$ calculated from the forward and reverse rate constants was approximately 5 $\times 10^{-10} \mathrm{M}$. These results are in good agreement with the equilibrium saturation experiments for $\left[{ }^{3} \mathrm{H}\right] N$-methylscopolamine binding (shown in Fig. 3). At equilibrium, specific binding of $\left[{ }^{3} \mathrm{H}\right] \mathrm{N}$-methylscopolamine followed a typical absorption isotherm. Nonspecific binding increased linearly with increasing concentrations of $\left[{ }^{3} \mathrm{H}\right] N$ methylscopolamine and was approximately $20 \%$ of specific binding at saturation (data not shown). A Scatchard plot of specific $\left[{ }^{3} \mathrm{H}\right] N$-methylscopolamine binding (Fig. 3 , inset) gave a straight line with a negative reciprocal slope of $3.7 \times 10^{-10} \mathrm{M}$ (the apparent dissociation constant). This is within experimental error of the $K_{\mathrm{D}}$ calculated from the forward and reverse rate constants and is similar to the $K_{\mathrm{D}}$ of approximately 2.5 to $4.0 \times 10^{-10} \mathrm{M}$ determined from equilibrium binding of $\left[{ }^{3} \mathrm{H}\right] \mathrm{QNB}$ (data not shown). The intercept of the Scatchard plot shown in Figure 3 indicated a maximum number of binding sites equal to $16 \mathrm{fmol} / \mathrm{mg}$ of total nematode protein. This experiment was carried out on a 90 to $95 \%$ pure adult population of the wild type, and repeated saturation experiments on similar populations gave values of 11.0 and $10.8 \mathrm{fmol}$ of $\left[{ }^{3} \mathrm{H}\right] N$-methylscopolamine binding sites per mg of protein. 


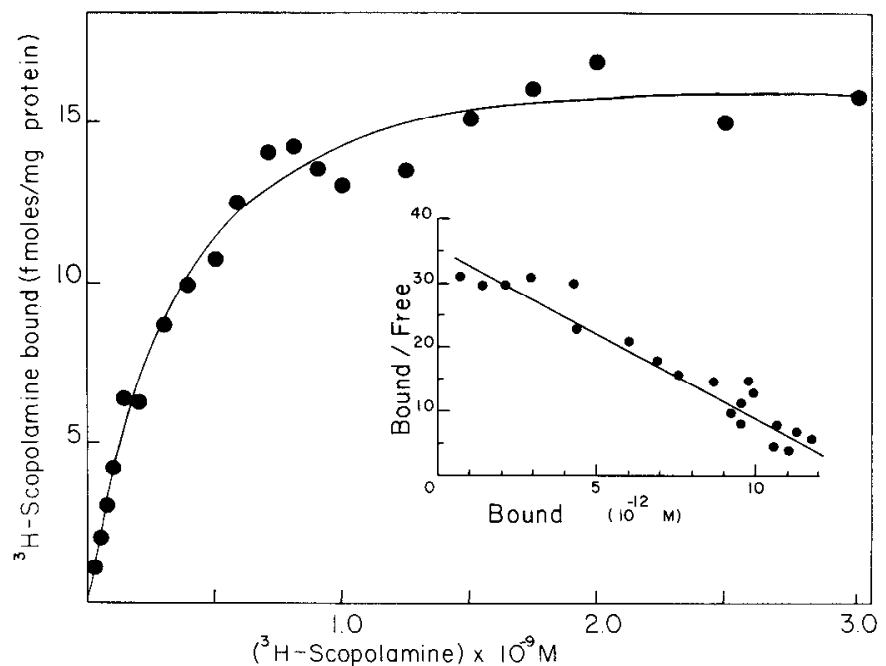

Figure 3. Concentration dependence of $\left[{ }^{3} \mathrm{H}\right] N$-methylscopolamine binding to crude homogenates of wild-type C. elegans. A crude homogenate of an adult-enriched population of $C$. elegans was incubated at $23^{\circ} \mathrm{C}$ with increasing concentrations of $\left.{ }^{3} \mathrm{H}\right] N$-methylscopolamine for $90 \mathrm{~min}$ in $50 \mathrm{~mm}$ sodium phosphate buffer ( $\mathrm{pH} 7.4)$. Each reaction volume of $1 \mathrm{ml}$ contained $0.7 \mathrm{mg}$ of crude protein. Suspensions were diluted with cold buffer and filtered for assay as described in "Materials and Methods." Nonspecific binding (not shown) was determined in the presence of $10^{5} \mathrm{M}$ atropine at each concentration of $\left[{ }^{3} \mathrm{H}\right] N$-methylscopolamine. Specific binding $(O)$ was calculated as the difference between total and nonspecific binding. Points represent the difference of the means of three separate assays for both total and nonspecific binding. Standard errors were all less than $10 \%$ of the mean for each point. Inset: Scatchard plot of specific binding.

Saturation experiments were also performed on synchronous adult populations grown from a pure population of developing embryos obtained by chlorox treatment of egg-bearing adults. These results, summarized in Table III, show that binding levels in synchronous wild-type adult populations $(9.64 \pm 2.35 \mathrm{fmol} / \mathrm{mg}$ of protein) are somewhat less on the average than for adult-enriched populations, possibly because fewer juveniles contaminated the synchronous populations.

For two strains we compared the concentration of $\left[{ }^{3} \mathrm{H}\right]$ $N$-methylscopolamine binding sites in adult-enriched populations and in juvenile populations (consisting of $100 \% \mathrm{~L} 1$ and L2 larvae). In one experiment, the wild-type adult concentration of $\left[{ }^{3} \mathrm{H}\right] N$-methylscopolamine binding sites was $11.0 \mathrm{fmol} / \mathrm{mg}$ of protein whereas the juvenile concentration was $38.5 \mathrm{fmol} / \mathrm{mg}$ of protein. In another experiment, the concentration of $\left[{ }^{3} \mathrm{H}\right] N$-methylscopolamine binding sites in an adult-enriched population of strain X37 was $13.0 \mathrm{fmol} / \mathrm{mg}$ of protein and the juvenile concentration was $59.9 \mathrm{fmol} / \mathrm{mg}$ of protein. Equilibrium saturation experiments are being carried out with homogeneous populations of L1 larvae to determine whether larval binding sites are qualitatively different from those of adults.

The affinity of binding sites for various cholinergic compounds was measured in equilibrium competition experiments. In these experiments, the concentration of added $\left[{ }^{3} \mathrm{H}\right] N$-methylscopolamine was held constant and competitors were added in increasing amounts. The re- sults, shown in Figure 4 and summarized in Table I, indicate that the $\left[{ }^{3} \mathrm{H}\right] \mathrm{N}$-methylscopolamine binding sites in nematode homogenates resemble, to a large extent, muscarinic acetylcholine receptors found in vertebrates (Burgermeister et al., 1978; Yamamura and Snyder; 1974a, b: Yamamura et al., 1974). Potent, highly specific muscarinic antagonists blocked the binding of $\left[{ }^{3} \mathrm{H}\right] \mathrm{N}$ methylscopolamine with $K_{\mathrm{i}}$ values in the nanomolar range. The sites showed a much lower affinity for agonists, as is the case for vertebrate receptors. The muscarinic specific drug oxotremorine was the most potent agonist tested $\left(K_{\mathrm{i}}=1.2 \times 10^{-6} \mathrm{M}\right)$. Competition by acetylcholine was critically dependent upon prior blockade of acetylcholinesterase by eserine and partial blockade resulted in much greater apparent $K_{\mathrm{i}}$ values. These data make it clear that $\left[{ }^{3} \mathrm{H}\right] N$-methylscopolamine was not binding to acetylcholinesterase, an enzyme that has a high activity in nematodes (Johnson et al., 1981; Culotti et al., 1981). The nicotinic drug most potent in blocking $\left[{ }^{3} \mathrm{H}\right] N$-methylscopolamine binding was $d$-tubocurarine

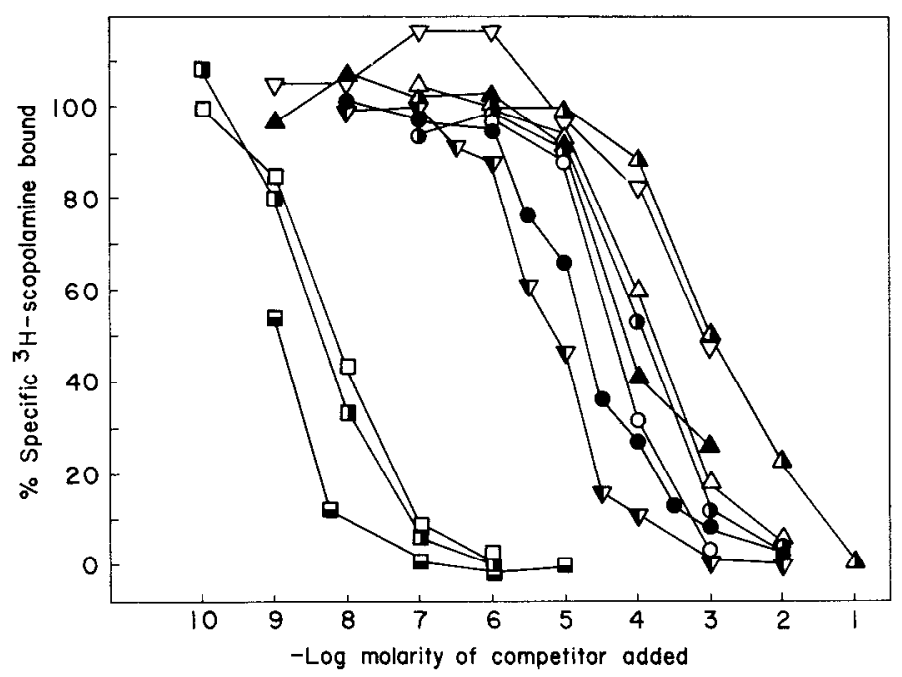

Figure 4. Competitition with $\left[{ }^{3} \mathrm{H}\right] N$-methylscopolamine for binding sites by cholinergic drugs. Specific binding of added $\left[{ }^{3} \mathrm{H}\right] N$-methylscopolamine to crude homogenates was determined in the presence of the indicated concentration of cholinergic drugs. Each point represents the average of three separate 1-ml assays. Standard errors (not shown) varied from 0.5 to $5 \%$ of the average. Competitions were performed on different occasions so conditions varied as indicated below: $\mathbb{U}$ : atropine, $0.60 \mathrm{mg}$ of protein/1-ml assay, $1.8 \mathrm{nM}\left[{ }^{3} \mathrm{H}\right] N$-methylscopolamine; $\boxminus$ : scopolamine, $0.60 \mathrm{mg}$ of protein $/ 1-\mathrm{ml}$ assay, $1.8 \mathrm{nM}\left[{ }^{3} \mathrm{H}\right]$ $N$-methylscopolamine; $\boldsymbol{\Delta}$ : carbachol, $0.60 \mathrm{mg}$ of protein/1-ml assay, $1.8 \mathrm{nM}\left[{ }^{3} \mathrm{H}\right] N$-methylscopolamine; $\bigcirc$; levamisole, $0.65 \mathrm{mg}$ of protein/1-ml assay, $1.3 \mathrm{nM}\left[{ }^{3} \mathrm{H}\right] N$-methylscopolamine; $\square$ : QNB, $0.65 \mathrm{mg}$ of protein/1-ml assay, $1.3 \mathrm{nM}\left[{ }^{3} \mathrm{H}\right] N$-methylscopolamine; $\triangle$ : acetylcholine, $0.65 \mathrm{mg}$ of protein/1-ml assay, $1.3 \mathrm{nM}\left[{ }^{3} \mathrm{H}\right] N$-methylscopolamine; $\boldsymbol{\nabla}$ oxotremorine, $0.67 \mathrm{mg}$ of protein/1-m] assay, $1.5 \mathrm{nM}\left[{ }^{3} \mathrm{H}\right] N$-methylscopolamine; 0 : nicotine, $0.67 \mathrm{mg}$ of protein $/ 1-\mathrm{ml}$ assay, $1.5 \mathrm{nM}\left[{ }^{3} \mathrm{H}\right] N$-methylscopolamine; $d$-tubocurarine, $0.67 \mathrm{mg}$ of protein/1-ml assay, 1.5 nM $\left[{ }^{3} \mathrm{H}\right] N$-methylscopolamine; $\boldsymbol{\Delta}$ : decanthonium, $0.56 \mathrm{mg}$ of protein/1-ml assay, $1.7 \mathrm{nM}\left[{ }^{3} \mathrm{H}\right] N$-methylscopolamine; $\nabla$ : hexamethonium, $0.56 \mathrm{mg}$ of protein $/ 1-\mathrm{ml}$ assay, $1.7 \mathrm{~nm}\left[{ }^{3} \mathrm{H}\right] N$-methylscopolamine. The acetylcholine competition was carried out on a crude homogenate of the acetylcholinesterase-deficient single mutant strain GG202 (ace-2) and it also contained 50 $\mu \mathrm{M}$ eserine sulfate. 
TABLE I

Approximate $K_{i}$ s for a variety of cholinergic agonists and antagonists calculated from competition experiments with $\left[{ }^{3} \mathrm{H}\right] \mathrm{QNB}$ and $\left[{ }^{3} \mathrm{H}\right] \mathrm{N}$-methylscopolamine

Competitions were performed as described in "Materials and Methods" with radioactive ligand concentrations that varied from 5.5 $\times 10^{-10}$ to $2.2 \times 10^{-9} \mathrm{M}$ in different experiments.

\begin{tabular}{|c|c|c|c|}
\hline & \multicolumn{2}{|c|}{$\left[{ }^{3} \mathrm{H}\right] \mathrm{QNB}$} & $\begin{array}{l}{\left[{ }^{3} \mathrm{H}\right] N \text {-methyl- }} \\
\text { scopolamine }\end{array}$ \\
\hline & \multicolumn{2}{|c|}{ Approximate $K_{\mathrm{i}}$} & Approximate $K_{\mathrm{i}}$ \\
\hline & \multicolumn{2}{|c|}{$M$} & $M$ \\
\hline Atropine & $1.5 \times 10^{-10}$ & $5.6 \times 10^{-10}$ & $6.9 \times 10^{-10}$ \\
\hline Scopolamine & $2.1 \times 10^{-9}$ & & $2.8 \times 10^{-10}$ \\
\hline Oxotremorine & $1.4 \times 10^{-5}$ & $1.1 \times 10^{-5}$ & $1.2 \times 10^{-6}$ \\
\hline$d$-Tubocurarine & $3.3 \times 10^{-5}$ & & $3.1 \times 10^{-6}$ \\
\hline Carbachol & $1.0 \times 10^{-4}$ & $3.0 \times 10^{4}$ & $1.7 \times 10^{-4}$ \\
\hline Acetylcholine $^{a}$ & $1.4 \times 10^{-4}$ & & $1.5 \times 10^{-4}$ \\
\hline Nicotine & $2.5 \times 10^{-4}$ & & $1.2 \times 10^{-4}$ \\
\hline Arecoline & $5.7 \times 10^{-6}$ & & \\
\hline Levamisole & & & $1.2 \times 10^{-5}$ \\
\hline$(+)$-Benzetimide & & & $3.8 \times 10^{-10}$ \\
\hline (-)-Benzetimide & & & $3.8 \times 10^{-8}$ \\
\hline Decamethonium & & & $1.2 \times 10^{-5}$ \\
\hline Hexamethonium & & & $1.4 \times 10^{-4}$ \\
\hline QNB & & & $1.4 \times 10^{-9}$ \\
\hline
\end{tabular}

${ }^{a}$ Contained $50 \mu \mathrm{M}$ eserine and performed on strain GG198 (ace-2; ace-1) for $\left[{ }^{3} \mathrm{H}\right] \mathrm{QNB}$ binding and on strain GG202 (ace-2) for $\left[{ }^{3} \mathrm{H}\right] N$ methylscopolamine binding.

which had a $K_{\mathrm{i}}$ of $3.3 \times 10^{-6} \mathrm{M}$, about 15,000-fold greater than the most potent muscarinic drug. Similar competition experiments were done to test the pharmacology of the $\left[{ }^{3} \mathrm{H}\right] \mathrm{QNB}$ binding sites, and the results also are summarized in Table I. In general the $K_{\mathrm{i}}$ values agree well with those determined for $\left[{ }^{3} \mathrm{H}\right] N$-methylscopolamine binding. This would be expected if both muscarinic radioligands bound to the same site and had similar $K_{\mathrm{D}}$ values. The data were somewhat more scattered with $\left[{ }^{3} \mathrm{H}\right] \mathrm{QNB}$ binding than with $\left[{ }^{3} \mathrm{H}\right] N$-methylscopolamine because of its higher nonspecific binding and poorer signal-to-noise ratio.

In addition to the pharmacologic specificity, we also tested the stereospecificity of the $\left[{ }^{3} \mathrm{H}\right] N$-methylscopolamine binding sites. Competition experiments with the $(+)$ and $(-)$ enantiomers of benzetimide showed that the $(+)$ enantiomer was at least 100 -fold more effective a competitor than the (-) enantiomer (Fig. 5 and Table I). This also is true of vertebrate muscarinic receptors (Beld and Ariens, 1974).

The availability of acetylcholinesterase mutants suggested the possibility of testing whether muscarinic binding sites in the nematode may be regulated by cholinergic stimulation. Such regulation has been observed for muscarinic receptors in cultures of neuron-like cloned cells and CNS cells (Klein et al., 1979; Siman and Klein, 1979) and also in animals treated with acetylcholinesterase inhibitors (Schiller, 1979). If analogous regulation occurs in nematodes, then mutants that diminish acetylcholinesterase activity in vivo might be expected to exhibit lower levels of muscarinic binding sites than controls. Table II shows binding levels in homogenates of 90 to 95\% pure adult populations of wild-type and acetylcholinesterase-deficient mutants. Binding levels in mutants and wild type were not significantly different. Even the acetylcholinesterase double mutant GG198 (p1000, g73), which is $98 \%$ deficient in acetylcholinesterase activity (Culotti et al., 1981), exhibited a concentration of $\left[{ }^{3} \mathrm{H}\right]$ QNB binding sites comparable to wild type. Although the results with these mutants are difficult to interpret precisely, they do suggest that down regulation in nematodes, if it occurs at all, is not as extensive as described for vertebrate cells.

A pharmacological approach designed to answer the same question was carried out by adding an exogenous acetylcholinesterase inhibitor to live worms. The inhibitor Aldicarb was chosen because of its known effectiveness in nematode systems. It induces severe developmental defects even on wild-type nematodes when used at concentrations of 0.5 to $1.0 \mathrm{~mm}$ (Culotti et al., 1981; J. G. Culotti, manuscript in preparation), suggesting that at these concentrations maximal in vivo inhibition of ace-

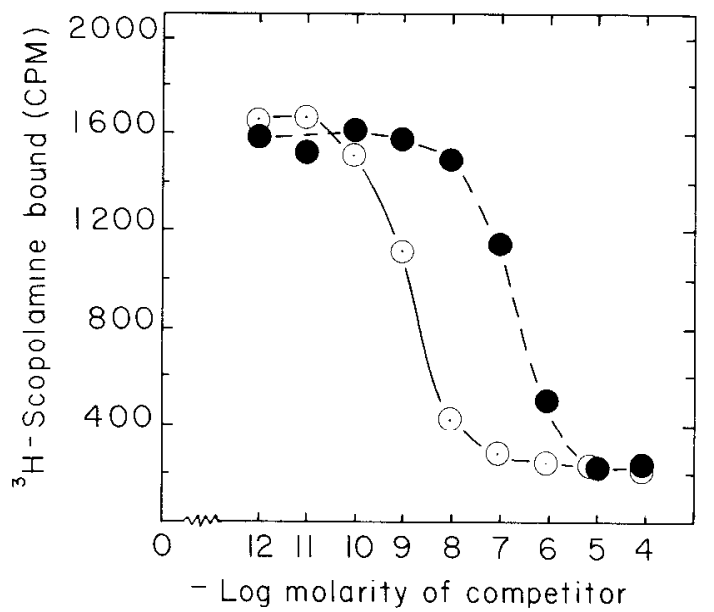

Figure 5. Competition with $\left[{ }^{3} \mathrm{H}\right] N$-methylscopolamine for binding sites by $(+)$ and $(-)$ enantiomers of benzetimide. Total binding of added $1.6 \mathrm{nM}\left[{ }^{3} \mathrm{H}\right] N$-methylscopolamine to $0.61 \mathrm{mg}$ of crude nematode protein (1-ml assays) was determined in the presence of the indicated concentrations of $(1) \odot$ or $(-)(\odot)$ benzetimide. Total binding in the presence of $10^{-5} \mathrm{M}$ atropine was equal to $229 \mathrm{cpm}$ in the same experiment. Each point represents the average of three separate assays. Standard errors were all less than $10 \%$ of the average.

TABLE II

Levels of $\left[{ }^{3} H\right] Q N B$ binding in adult-enriched populations of wildtype and acetylcholinesterase-deficient mutants of C. elegans

Binding site concentrations were determined at saturating levels of $\left[{ }^{3} \mathrm{H}\right] \mathrm{QNB}$ equivalent to $1.3 \times 10^{-9} \mathrm{M}$ as described in "Materials and Methods." Protein concentrations in the assay were $0.5 \mathrm{mg} / \mathrm{ml}$ for N2, $0.48 \mathrm{mg} / \mathrm{ml}$ for PR1000, $0.55 \mathrm{mg} / \mathrm{ml}$ for GG202, and $0.48 \mathrm{mg} / \mathrm{ml}$ for GG201. Indicaled binding site concentrations represent the average of five determinations for total binding minus the average of six determinations for nonspecific binding. Percentages of errors were determined by the interval estimation of the difference of two normal means with $95 \%$ confidence.

\begin{tabular}{llc}
\hline Strain & Mutant Gene(s) & {$\left[{ }^{\prime} \mathrm{H}\right] \mathrm{QNB}$ bound } \\
\hline & & fmoles $/$ mg protein \\
N2 & Wild type & $15.6 \pm 2.0$ \\
PR1000 & ace-1 & $15.9 \pm 3.7$ \\
GG202 & ace-2 & $18.6 \pm 1.9$ \\
GG201 & ace-1; ace-2 & $18.9 \pm 2.0$ \\
\hline
\end{tabular}


tylcholinesterase activity has been achieved. Moreover, at lower concentrations of Aldicarb (50 to $100 \mu \mathrm{M})$, ace-2 single mutants and ace-1, ace-2 double mutants are more severely growth inhibited than ace-1 single mutants or wild type, suggesting that the in vivo effects of Aldicarb are at least partially brought about by inhibition of ace1 -controlled acetylcholinesterase (i.e., those forms present in the ace-2 mutants) (Culotti et al., 1981; J. G. Culotti, manuscript in preparation). Adult-enriched populations or juvenile-enriched populations were grown 2 days at $20^{\circ} \mathrm{C}$ in $1 \mathrm{~mm}$ Aldicarb, harvested, freeze-powdered, and assayed for $\left[{ }^{3} \mathrm{H}\right] N$-methylscopolamine binding levels. An untreated adult-enriched population of nematodes was also assayed as a control. Binding levels in Aldicarb-treated adults $(25 \mathrm{fmol} / \mathrm{mg}$ of protein) were higher than binding levels in untreated adults (15 fmol/ $\mathrm{mg}$ of protein); however, it should be noted that the untreated adult population may not represent the perfect control. This is because Aldicarb does not prevent egg laying and halching, but does block morphologic development (increase in size) of the hatchees. So the population of adults left on Aldicarb for nearly 2 days laid eggs which hatched. This population was, therefore, contaminated with blocked L1 stage larvae. The apparent increase in binding levels over untreated adults (collected independently) may, therefore, reflect a degree of contamination of this adult population with these next generation larvae. This was not a problem with Aldicarbtreated larvae since these remained morphologic juveniles and there was no increased heterogeneity in the population. The concentration of binding sites in Aldicarb-treated L1 and L2 larvae was $50.5 \mathrm{fmol} / \mathrm{mg}$ of protein which was approximately equal to the concentration of binding sites in untreated L1 and L2 larvae ( $38.5 \mathrm{fmol} /$ $\mathrm{mg}$ of protein) determined in a previous experiment. These results show that little or no down regulation of $\left[{ }^{3} \mathrm{H}\right] \mathrm{QNB}$-binding sites occurs under conditions designed to chronically elevate in vivo concentrations of acetylcholine over a period of 2 days. In fact, if anything, receptor levels increased as a result of treatment.

Although inhibition of acetylcholinesterase activity might be expected to enhance synaptic acetylcholine levels, no proof of this assumption has been obtained. A more direct experiment was carried out by treating animals with a concentration of the putative cholinergic agonist levamisole (Lewis et al., 1980b) sufficient to induce severe contraction of the body wall musculature. As shown in Figure 4, levamisole blocked binding of $\left[{ }^{3} \mathrm{H}\right] N$ methylscopolamine to wild-type homogenates with a $K_{\mathrm{i}}$ of $1.2 \times 10^{-5} \mathrm{M}$. A large population of wild-type larvae and an adult-enriched population were collected as described in "Materials and Methods." Some of each population was frozen immediately and the remainder was placed onto growth plates containing bacteria and $1 \mathrm{~mm}$ levamisole. The plates were incubated for $32 \mathrm{hr}$ at room temperature and the animals were harvested, cleaned, and frozen in liquid nitrogen. Treated and untreated populations were freeze-powdered, and the number of binding sites in each of the crude homogenates was determined. The concentration of $\left[{ }^{3} \mathrm{H}\right] N$-methylscopolamine-binding sites in levamisole-treated larvae was $38 \mathrm{fmol} / \mathrm{mg}$ of protein, whereas in untreated larvae the concentration was $40 \mathrm{fmol} / \mathrm{mg}$ of protein. Similarly, the concentration of $\left[{ }^{3} \mathrm{H}\right] N$-methylscopolamine-binding sites in the levamisole-treated adult-enriched population was $23 \mathrm{fmol} / \mathrm{mg}$ of protein versus $26 \mathrm{fmol} / \mathrm{mg}$ of protein in untreated adults. These results show that direct prolonged treatment of nematodes with concentrations of levamisole causing severe hypercontraction of the body musculature does not result in significant down regulation of muscarinic binding sites.

Two classes of cholinergic drug-resistant mutants have been selected for potential acetylcholine receptor changes. The first class of mutants was isolated for resistance to the acetylcholinesterase inhibitor Aldicarb (J. G. Culotti, manuscript in preparation). The resistance mutations were isolated in a strain (GG198) that already contained mutations in two genes, ace-1 and ace-2, which produced a $98 \%$ deficiency in acetylcholinesterase activity (Culotti et al., 1981). The rationale for this selection was as follows: if the developmental defect induced by Aldicarb results from the action of elevated acetylcholine levels in cholineryic synapses (possibly induced by further inhibiting the $2 \%$ residual acetylcholinesterase activity in the ace-1, ace-2 double mutant), then one way to alleviate or bypass such a defect might be to genetically alter the postsynaptic receptor. In other words, Aldicarbresistant mutants of the acetylcholinesterase double mutants might carry a compensating genetic defect in an acetylcholine receptor structural gene. Consequently, $\left[{ }^{3} \mathrm{H}\right] \mathrm{QNB}$ or $\left[{ }^{3} \mathrm{H}\right] N$-methylscopolamine binding levels were determined for crude homogenates of several of the Aldicarb-resistant mutants. The results summarized in Table III indicate that none of these mutants is grossly deficient in $\left[{ }^{3} \mathrm{H}\right] \mathrm{QNB}$ binding sites, although subtle deficiencies may exist.

The second class of mutants was isolated by Brenner (1974) and by Lewis et al. 1980a) for resistance to levamisole (a component of tetramisole). Crude homogenates of these mutants were also assayed for $\left[{ }^{3} \mathbf{H}\right] N$-methylscopolamine binding and the concentration of binding sites is summarized in Table III. As for the Aldicarbresistant mutants, none of the levamisole-resistant mutants exhibited gross deficiencies in the concentration of $\left[{ }^{3} \mathrm{H}\right] N$-methylscopolamine binding sites compared with the wild type, although, once again, subtle deficiencies may exist.

\section{Discussion}

These studies show that nematodes contain sites capable of binding the highly specific muscarinic antagonists $\left[{ }^{3} \mathrm{H}\right] N$-methylscopolamine and $\left[{ }^{3} \mathrm{H}\right] \mathrm{QNB}$ and that these sites have pharmacological characteristics similar but not identical to vertebrate muscarinic acetylcholine receptors. One difference of possible physiological interest is the apparent lack of receptor regulation in the nematode system; mutations and pharmacological treatments expected to alter levels of cholinergic stimulation had little or no influence on receptor concentration. The data represent the first characterization of binding sites for any neurotransmitter in the nematode system, and they suggest the possibility of extending genetic analysis of cholinergic synapses in nematodes, previously focused on acetylcholinesterases, to another important molecular component.

Several lines of evidence indicate that the specific 
TABLE III

Concentrations of $\left[{ }^{3} \mathrm{H}\right] \mathrm{N}$-methylscopolamine binding sites in wild-type and cholinergic mutants of C. elegans

Binding site concentrations were determined in standard assays (see "Materials and Methods") at saturating levels of $\left[{ }^{3} \mathrm{H}\right] N$-methylscopolamine equivalent to $1.74 \times 10^{-9} \mathrm{M}$ for experiment a, $2.43 \times 10^{-9} \mathrm{M}$ for experiment $\mathrm{b}, 2.30 \times 10^{-9} \mathrm{M}$ for experiment $\mathrm{c}, 1.73 \times 10^{-9} \mathrm{M}$ for experiment $\mathrm{d}$, 1.22 $\times 10^{-9} \mathrm{M}$ for experiment $\mathrm{e}$, and $2.22 \times 10^{-9} \mathrm{M}$ for experiment $\mathrm{f}$. Protein concentrations in the 1-ml assays varied from 0.30 to $1.16 \mathrm{mg}$, but were generally in the range of 0.4 to $0.8 \mathrm{mg}$ for different mutants. Indicated binding site concentrations represent the average of five determinations for total binding minus the average of five determinations for nonspecific binding. Standard errors for multiple determinations were all less than $10 \%$ of the mean.

\section{Wild Type}

19 determinations of $3 \mathrm{H}-\mathrm{N}$-methylscopolamine binding site concentrations Mean $=9.64 \mathrm{fmoles} / \mathrm{mg}$ protein Standard deviation $=2.35 \mathrm{fmoles} / \mathrm{mg}$ protein

Variation within the same synchronous population

\begin{tabular}{|c|c|c|c|}
\hline Population & fmoles/mg protein & Population & fmoles/mg protein \\
\hline$\# 1^{a}$ & 8.8, & $\# 4^{a}$ & 8.2, \\
\hline$\# 2^{a}$ & $10.6,12.9$ & $\# 5$ & $8.8,11.9$ \\
\hline \#3 & $15.0,11.0$ & $\$ 6$ & $6.3,9.3$ \\
\hline
\end{tabular}

\section{Levamisole Resistant Mutants}

$\begin{array}{lll}\text { Strain } & \text { Gene } & \text { Allele } \\ \text { N2 } & \begin{array}{l}\text { wild } \\ \text { type }\end{array} & \\ \text { CB1072 } & \begin{array}{l}\text { unc-29 } \\ \text { unc-63 }\end{array} & \text { e1072 } \\ \text { CB384 } 384 \\ \text { ZZ13 } & \text { lev-7 } & \text { x13 } \\ \text { ZZ15 } & \text { lev-8 } & \text { x15 } \\ \text { ZZ16 } & \text { lev-9 } & \text { x16 } \\ \text { ZZ17 } & \text { lev-10 } & \text { x17 } \\ \text { ZZ12 } & \text { lev-11 } & \text { x12 } \\ \text { CB66 } & \text { unc-22 } & \text { e66 } \\ \text { ZZ19 } & \text { unc-74 } & \text { x19 } \\ \text { CB306 } & \text { unc-50 } & \text { e306 } \\ \text { ZZ21 } & \text { lev-1 } & \text { x21 } \\ \text { CB211 } & \text { lev-1 } & \text { e211 } \\ \text { CB904 } & \text { unc-38 } & \text { e } 904 \\ \text { CB540 } & \text { unc-68 } & \text { e540 }\end{array}$

\section{Aldicarb Resistant Mutants}

\begin{tabular}{llr} 
Strain & Phenotype & \\
\hline N2 & wild & \\
& type & 15 \\
NW7 & pseudow11d type & 9 \\
NW29 & paralyzed & 8 \\
NW57 & paralyzed & 7 \\
NW86 & paralyzed & 7 \\
CB450 & paralyzed & \\
NW17 & pseudowild type & \\
NW27 & paralyzed & \\
NW96 & pseudowild type \\
NW50 & paralyzed & \\
NW119 & paralyzed \\
NW100 & pseudowild type
\end{tabular}

Concentration of $3 \mathrm{H}-\mathrm{N}-$ methylscopolamine Binding Sites (fmoles/mg protein) in Different Experiments ( $a, b, c, d, e, f)$

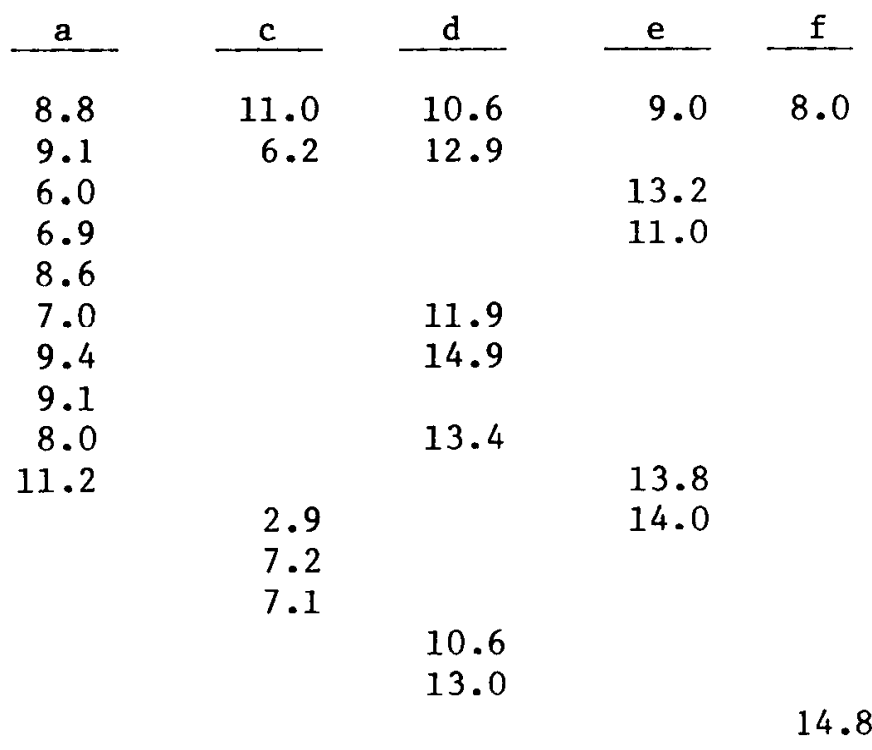

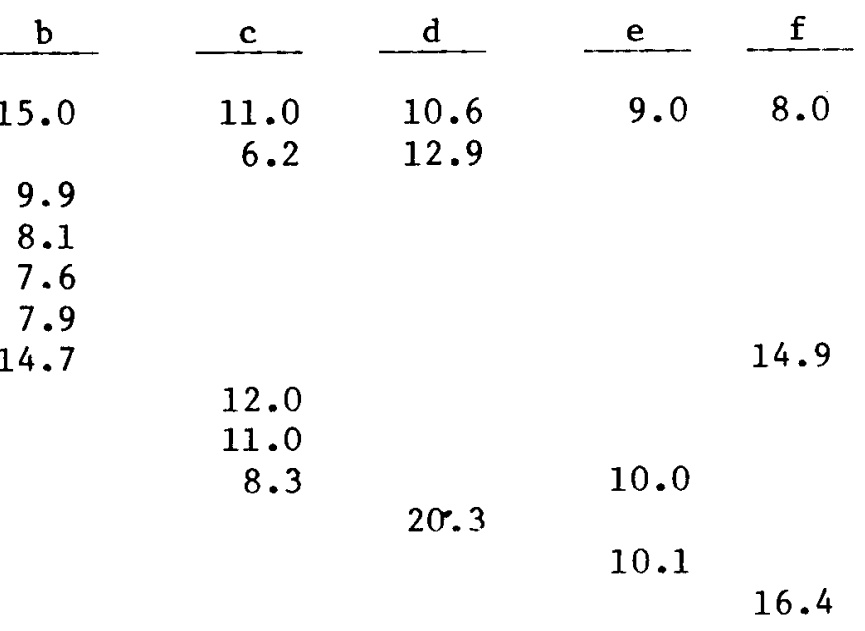

a determinations made in the same experiment under equivalent conditions. 
radioligand binding observed here is to muscarinic receptors. First, binding of the labeled muscarinic antagonists is saturable and shows very high affinity. The dissociation constant obtained from equilibrium experiments for scopolamine $\left(3.7 \times 10^{-10} \mathrm{M}\right)$ is indistinguishable from that obtained in vertebrate neural cell lines (Burgermeister et al., 1978). The dissociation constant of $\left[{ }^{3} \mathrm{H}\right] \mathrm{QNB}$, determined somewhat less accurately because of higher nonspecific binding, was about 2.5 to $4 \times 10^{-10} \mathrm{M}$. This is equal to or only slightly higher than constants obtained for other systems (Burgermeister et al., 1978; Siman and Klein, 1979). Second, the equilibrium determination of the dissociation constant was essentially equal to that obtained from the ratio of the kinetic rate constants (5 $\times 10^{-10} \mathrm{M}$ ). The forward and reverse rate constants for $\left[{ }^{3} \mathrm{H}\right] N$-methylscopolamine binding $\left(3 \times 10^{6} \mathrm{liter} / \mathrm{mol}\right.$-sec and $1.6 \times 10^{-3} / \mathrm{sec}$, respectively) also were within the range for other receptors (Burgermeister et al., 1978). Third, the maximum number of binding sites was approximately $15 \mathrm{fmol} / \mathrm{mg}$ of protein in an asynchronous adult-enriched population whether determined with saturating levels of $\left[{ }^{3} \mathrm{H}\right] N$-methylscopolamine or $\left[{ }^{3} \mathrm{H}\right] \mathrm{QNB}$, consistent with the labeling of the same sites by the two ligands. This level of sites, normalized to total protein of the organism, is about 60- to 70-fold less than the highest density of sites found in regions of the mammalian brain (Yamamura et al., 1974a). However, it is as large as the number of sites found in neuroblastoma and neuron-like hybrid clones (Klein et al., 1979; Shifrin and Klein, 1980) that have been used profitably to study various aspects of muscarinic receptor activity and control. It appears likely, therefore, that some cells in the nematode have high levels of muscarinic binding sites. Finally, binding of radioligands was blocked at very low doses by highly specific muscarinic antagonists. Muscarinic and mixed cholinergic agonists blocked binding at higher doses, as typically is the case for muscarinic receptor systems. The approximate $K_{\mathrm{i}}$ values for agonists were slightly higher than those seen in vertebrates. It is known, however, that a large number of factors can specifically influence muscarinic receptor affinity for agonists without changing the properties of antagonist binding $(H$. R. Chin and W. L. Klein, submitted for publication; Klein, 1980a). The sites also appear to differ pharmacologically from vertebrate muscarinic receptors by having somewhat higher sensitivity to nicotinic agents than seen, for example, in mammalian synaptosomes (Burgen et al., 1974). Isolation and analysis of binding moieties from vertebrates and nematodes labeled with the covalent antagonist $\left[{ }^{3} \mathrm{H}\right]$ propylbenzylcholine mustard may provide more information about differences in future work.

The physiological function of muscarinic binding sites in nematodes is not established. In preliminary work, Lewis et al. (1980b) have found that the antagonist QNB potentiates the rate of muscle contraction of cut worms induced by nicotine and carbachol, suggesting an inhibitory function for muscarinic activity. Very high doses of atropine completely blocked all induced muscle contraction, likely by secondary effects of the drug. More direct evidence concerning muscarinic action would require the ability to perform electrophysiological experiments on the nematode nervous system. While this is currently not feasible with $C$. elegans because of its small size, the ability to stimulate and record from neurons in the closely related parasitic nematode $A$. lumbricoides has recently been demonstrated (R. E. Davis and A. O. W. Stretton, personal communication). Many of the questions about the physiology of muscarinic receptors in nematodes should, therefore, be answerable with $A s$ caris.

Developmentally, the concentration of $\left[{ }^{3} \mathrm{H}\right] \mathrm{QNB}$ and $\left[{ }^{3} \mathrm{H}\right] N$-methylscopolamine binding sites was 3 - to 4 -fold higher in young L1 larvae (40 to $60 \mathrm{fmol} / \mathrm{mg}$ of protein) than in adults (10 to $15 \mathrm{fmol} / \mathrm{mg}$ of protein), despite the fact that adults are approximately 100 -fold larger in volume. Similar results have been obtained for acetylcholinesterase activity in the nematode, whereby activity increases approximately 25-fold per animal with development from L1 larvae to adults (Culotti et al., 1981). This is consistent with the probable synaptic function of this enzyme, which by histochemical criteria appears to be limited to regions of the animal that are rich in nervous tissue (with the exception of the pharyngeointestinal valve cells which stain in wild-type and ace-1 mutants, but fail to stain in ace-2 mutants).

Since one of our long term goals is to identify receptor mutants of $C$. elegans, we considered it necessary to study the possible regulatory effects of internal factors such as chronic cholinergic stimulation on $\left[{ }^{3} \mathrm{H}\right] \mathrm{QNB}$ binding levels. Chronic stimulation in vertebrates results in lowered muscarinic receptor levels (Klein et al., 1979; reviewed Klein, 1980b) with a concomitant change in the physical state of the receptor $(H$. R. Chin and W. L. Klein, submitted for publication). In order to determine whether nematodes possess a similar regulatory mechanism for receptor levels, we initially tried two ways of chronically increasing synaptic acetylcholine levels in vivo: one was to measure the number of $\left[{ }^{3} \mathrm{H}\right] \mathrm{QNB}$ binding sites in acetylcholinesterase-deficient mutants, and the other was to measure $\left[{ }^{3} \mathrm{H}\right] \mathrm{QNB}$ binding sites in animals treated with the exogenously applied acetylcholinesterase inhibitor Aldicarb. In neither case was receptor concentration lower than in controls; if anything, the Aldicarb-treated animals had a higher level of binding sites than untreated controls. Possible changes in the physical state of receptors remain to be tested.

Direct stimulation by a known concentration of agonist in vivo would allow a more rigorous approach to the question of regulation. The closest we could come to this ideal situation was to add the putative cholinergic agonist levamisole to living nematodes. Levamisole induces a hypercontraction of the body musculature of C. elegans without killing the animals, an effect that is consistent with its purported role as a cholinergic agonist (Lewis et al., 1980b). Nevertheless, treatment of nematodes with levamisole for $32 \mathrm{hr}$ led to no decrease in the number of $\left[{ }^{3} \mathrm{H}\right] N$-methylscopolamine binding sites. Further studies will be needed to establish firmly the extent to which receptor regulatory mechanisms may exist in C. elegans. The failure to find regulatory effects as a result of prolonged agonist stimulation may indicate that nematodes have not evolved such regulatory mechanisms. It is possible that the small size of the nematode nervous system dictates that it be hard-wired and nonplastic. On the other hand, regulatory mechanisms may exist, but we have yet to find the proper method for increasing syn- 
aptic agonist levels, particularly muscarinic ones. Nevertheless, the results at present indicate that the number of $\left[{ }^{3} \mathrm{H}\right] \mathrm{QNB}$ or $\left[{ }^{3} \mathrm{H}\right] N$-methylscopolamine binding sites are not easily altered by internal or external influences, indicating that it should be possible to identify receptor structural gene mutants by virtue of their lack of binding sites.

Our initial screening of mutants has not uncovered any receptor-deficient phenotypes. 'There could be several reasons for our failure to find receptor mutants. First of all, such mutants, if they exist, could have deficiencies too subtle to be picked up by a single determination in our assay. There is clearly enough variability in the assay from one population of worms to the next and from day to day (Table I) that multiple determinations and statistical analysis would be required to ascertain whether a given mutant was partially deficient in muscarinic binding sites. However, a more likely reason for our failure to detect any $\left[{ }^{3} \mathrm{H}\right] N$-methylscopolamine binding site-deficient mutants is that we have not yet assayed the right class of mutants (it is also possible that an acetylcholine receptor-deficient mutant would be inviable and, therefore, could be isolated only as a conditional mutant). Finally, the most promising mutants have been screened only for $\left[{ }^{3} \mathrm{H}\right] \mathrm{QNB}$ or $\left[{ }^{3} \mathrm{H}\right] N$-methylscopolamine binding levels relative to the wild type. Preliminary experiments have shown low levels of specific ${ }^{125} \mathrm{I}-\alpha$-bungarotoxin binding sites in wild-type nematode extracts. These sites are distinct from the $\left[{ }^{3} \mathrm{H}\right] \mathrm{QNB}$ and $\left[{ }^{3} \mathrm{H}\right] N$-methylscopolamine binding types as determined by their specificity for various cholinergic agonists and antagonists. The possibility that one or more of the mutants is deficient in ${ }^{125} \mathrm{I}$ - $\alpha$-bungarotoxin binding sites is currently being checked.

\section{References}

Albertson, D. G., and J. N. Thomson (1976) The pharynx of Caenorhabditis elegans. Philos. Trans. R. Soc. Lond. [Biol.] 275: 299-325.

Beld, A. J., and E. J. Ariens (1974) Stereospecific binding as a tool in attempts to localize and isolate muscarinic receptors. Eur. J. Pharmacol. 25: 203-209.

Bradford, M. (1976) A rapid and sensitive method for quantitation of microgram quantities of protein using the principle of protein-dye binding. Anal. Biochem. 72: 248-254.

Brenner, S. (1974) The genetics of Caenorhabditis elegans. Genetics 77: 71-94.

Burgen, A. S. V., C. R. Hiley, and J. M. Young (1974) The properties of muscarinic receptors in mammalian cerebral cortex. Br. J. Pharmacol. 51: 279-285.

Burgermeister, W., W. L. Klein, M. Nirenberg, and B. Witkop (1978) Comparative binding studies with cholinergic ligands and histrionicotoxin at muscarinic receptors of neural cell lines. Mol. Pharmacol. 14: 240-256.

Chalfie, M., H. R. Horvitz, and J. E. Sulston (1981) Mutations that lead to reiterations in the cell lineages of Caenorhabditis elegans. Cell 24: 59-70.

Culotti, J., G. von Ehrenstein, M. R. Culotti, and R. L. Russell (1981) A second class of acetylcholinesterase-deficient mutants of the nematode Caenorhabditis elegans. Genetics 97: 281-305.

del Castillo, J., W. C. DeMello, and T. Morales (1963) The physiological role of acetylcholine in the neuromuscular system of Ascaris lumbricoides. Arch. Int. Physiol. 71: 741-747.
Deppe, U., E. Schierenberg, T. Cole, C. Krieg, D. Schmitt, B. Yoder, and G. von Ehrenstein (1978) Cell lineages of the embryo of the nematode Caenorhabditis elegans. Proc. Natl. Acad. Sci. U. S. A. 75: 376-380.

Dudai, Y., and J. Ben-Barak (1977) Muscaranic receptors in Drosophila melanogaster demonstrates binding of ${ }^{3} \mathrm{H}$-quinuclidinyl benzilate. FEBS Lett. 81: 134-136.

Galper, J. B., W. L. Klein, and W. A. Catterall (1977) Muscarinic acetylcholine receptors in developing chick heart. J. Biol. Chem. 252: 8692-8699.

Haim, N., S. Nahum, and Y. Dudai (1979) Properties of a putative muscarinic cholinergic receptor from Drosophila melanogaster. J. Neurochem. 32: 543-522.

Hall, D. (1978) The posterior nervous system of the nematode Caenorhabditis elegans. Thesis, California Institute of Technology.

Horvitz, H. R., and J. E. Sulston (1980) Isolation and genetic characterization of cell lineage mutants in the nematode Caenorhabditis elegans. Genetics 96: 435-454.

James, W. M., C. DeCrease, J. G. Culotti, and W. L. Klein (1980) Ligand binding to acetylcholine receptors in wild type and acetylcholinesterase-deficient strains of the nematode $C$. elegans. (Abstr.). Neuroscience 10: 256.

Johnson, C. D., J. G. Duckett, J. G. Culotti, R. K. Herman, P. M. Meneeley, and R. L. Russell (1981) An acetylcholinesterase-deficient mutant of the nematode Caenorhabditis elegans. Genetics 97: 261-279.

Klein, W. L. (1980a) Multiple binding states of muscarinic acetylcholine receptors from cloned neuroblastoma $\times$ glioma hybrid cells. Biochem. Biophys. Res. Commun. 93: 1058-1066.

Klein, W. L. (1980b) Regulation of muscarinic acetylcholine receptors. Proc. West. Pharmacol. Soc. 23: 449-458.

Klein, W. L., N. Nathanson, and M. Nirenberg (1979) Muscarinic acetylcholine receptor regulation by accelerated rate of receptor loss. Biochem. Biophys. Res. Commun. 90: 506-512.

Koelle, G. B. (1975) Parasympathomimetic agents. In The Pharmacological Basis of Therapeutics, L. S. Goodman and A. Gilman, eds., pp. 467-477, MacMillan, New York.

Lewis, J. A., C. H. Wu, H. Berg, and J. H. Levine (1980a) The genetics of levamisole resistance in the nematode Caenorhabditis elegans. Genetics 95: 905-928.

Lewis, J. A., C. H. Wu, J. H. Levine, and H. Berg (1980b) Levamisole-resistant mutants of the nematode Caenorhab. ditis elegans appear to lack pharmacological acetylcholine receptors. Neuroscience 5: 967-989.

Nathanson, N. M., W. L. Klein, and M. Nirenberg (1978) Regulation of adenylate cyclase activity mediated by muscarinic acetylcholine receptors. Proc. Natl. Acad. Sci. U. S. A. $75: 1788-1791$.

Purves, R. D. (1976) Function of muscarinic and nicotinic acetylcholine receptors. Nature 261: 149-151.

Schiller, G. D. (1979) Reduced binding of $\left({ }^{3} \mathrm{H}\right)$ quinuclidinyl benzilate associated with chronically low acetylcholinesterase activity. Life Sci. 24: 1159-1164.

Shifrin, G. S., and W. L. Klein (1980) Regulation of muscarinic acetylcholine receptor concentration in cloned neuroblastoma cells. J. Neurochem. 34: 993-999.

Siman, R. G., and W. L. Klein (1979) Cholinergic activity regulates muscarinic receptors in central nervous system cultures. Proc. Natl. Acad. Sci. U. S. A. 76: 4141-4145.

Sulston, J. E., and S. Brenner (1974) The DNA of Caenorhabditis elegans. Genetics 77: 95-104.

Sulston, J. E., and H. R. Horvitz (1977) Post embryonic cell lineages of the nematode Caenorhabditis elegans. Dev. Biol. 56: $110-156$.

Sulston, J. E., and H. R. Horvitz (1981) Abnormal cell lineages in mutants of the nematode Caenorhabditis elegans. Dev. Biol. 82: 41-55. 
von Ehrenstein, G., and E. Schierenberg (1980) Cell lineages and development of Caenorhabditis elegans and other nematodes. In Nematodes as Biological Models, B. M. Zuckerman, ed., Vol. 1, pp. 1-71, Academic Press, New York.

Ward, S., N. Thomson, J. G. White, and S. Brenner (1975) Electron microscopical reconstruction of the anterior sensory anatomy of the nematode Caenorhabditis elegans. J. Comp. Neurol. 160: 313-338.

Ware, R. W., D. Clark, K. Crossland, and R. L. Russell (1975) The nerve ring of the nematode Caenorhabditis elegans: Sensory input and motor output. J. Comp. Neurol. 162: 71110.

White, J. G., E. Southgate, J. N. Thomson, and S. Brenner
(1976) The structure of the ventral nerve cord of Caenorhabditis elegans. Philos. Trans. R. Soc. Lond. [Biol.] 275: 327342.

Yamamura, H. I., and S. H. Snyder (1974a) Muscarinic cholinergic binding in rat brain. Proc. Natl. Acad. Sci. U. S. A. 71: 1725-1729.

Yamamura, H. I., and S. H. Snyder (1974b) Muscarinic cholinergic receptor binding in the longitudinal muscle of the guinea pig ileum with ${ }^{3} \mathrm{H}$-quinuclidinyl benzilate. Mol. Pharmacol. 10: 861-867.

Yamamura, H. I., M. J. Kuhar, D. Greenberg, and S. H. Snyder (1974) Muscarinic cholinergic receptor binding: regional distribution in monkey brain. Brain Res. 66: 541-546. 